\title{
Alternative pavement heating technique using renewable energy in North Dakota
}

\author{
I-Hsuan $\mathrm{Ho}^{1, *}$, and Sheng $\mathrm{Li}^{2}$, and $\mathrm{Li} \mathrm{Ma}^{2}$ \\ ${ }^{1}$ Geology and Geological Engineering, University of North Dakota, USA \\ ${ }^{2}$ Civil Engineering, Lanzhou Jiaotong University, Visiting Scholar, University of North Dakota
}

\begin{abstract}
Hydronic heating pavement (HHP) is considered to be more sustainable and environmentalfriendly for de-icing or pavement heating. The more efficient approach is to use deep direct-use geothermal energy due to the high temperature and clean. In western North Dakota, several aquifers have been identified to provide geothermal hot water ranging from $34^{\circ} \mathrm{C}$ to $140^{\circ} \mathrm{C}$ within $2300 \mathrm{~m}$ below the ground surface. The current technique has made it feasible to utilize the hot water for power generation. Besides drilling new wells, the higher temperature water exits from power plant still has up to $70^{\circ} \mathrm{C}$. This temperature enables the valuable applications to cascading use for other purposes such as space heating, snow-melting for transportation infrastructure etc. This paper mainly focuses on studying the challenges of an HHP using geothermal water. Parametric studies using finite element analysis were conducted. Considering the high heat demands in western North Dakota due to the extreme weather, the suitable water temperatures, pipes layouts, mechanical properties of piped pavement, volumetric flow rates and thermal conductivity of pavement were analysed. The optimization of the HHP subject to different weather conditions and new findings are summarized and discussed.
\end{abstract}

\section{Introduction}

Snow and ice on pavements are used for numerous transportation problems and safety concerns, and significant inconvenience can be caused for travellers in terms of delays and accidents. In the past decade, many studies have focused on seeking economically viable deicing or effective snow-removal methods for airport pavements, bridge decks, and other transportation infrastructure. These studies have concentrated mainly on pavement heating techniques that are considered to be alternative snow-melting techniques ([1], [2], [3], [4], [5], [6]). Conventionally, snow removal strategies have relied on both mechanical and chemical methods. However, the mechanical methods are sometimes inefficient and timeconsuming and the chemical methods are detrimental to the environment. A hydronic heated pavement is considered to be more environmentally friendly and sustainable than conventional de-icing methods that use, for example, salts and chemicals. In fact, salts and chemicals are prohibited for use on airport pavements because they are detrimental to both pavement materials and to the metallic materials of aircraft ([7]).

According to the Federal Aviation Administration (FAA), heated pavement systems provide an alternative snow-removal strategy that can mitigate the effects of snowfalls by melting the snow and preventing it from bonding to the pavement surface ([2]). The benefits of pavement heating systems for airports include that they (1) have a positive impact on capacity during winter operations, (2) reduce the negative environmental impacts of chemical de-icers, (3) reduce the time required to clear priority areas, and (4) improve the operational status of the airport. To achieve these benefits of snow removal, several research projects were conducted to study advanced snow-melting techniques for airport infrastructure; these techniques include hydronic and electric pavement heating techniques. Several researchers have studied hydronic snow-melting systems as applied to transportation infrastructure using different heat sources ([8], [9], [10], [11], [12]).

\section{Hydronic Snow-Melting Systems}

The hydronic snow-melting method involves embedding pipes several inches beneath the surface of concrete pavement panels and circulating warm fluid through these pipes. The so-called Hydronic heating pavement (HHP) is considered to be more sustainable and environmentally friendly for dei-cing.

Specifically, the HHP is a closed-loop tube made of flexible polymer (e.g., cross-linked polyethylene, or PEX) in which a fluid or a mixture of hot water and glycol, depending on the type of heat source, circulates. The fluid is warmed to temperatures of $140^{\circ} \mathrm{F}$ to $180^{\circ} \mathrm{F}$ to provide sufficient heat for snow melting. Figure 1 illustrates a hydronic snow-melting pavement panel. Figure 1 (a) shows a three-dimensional view of a pipe-embedded concrete panel, Figure 1 (b) shows the top view of the pipe

\footnotetext{
* Corresponding author: ihsuan.ho@und.edu (I-Hsuan Ho)
} 
layout, and Figure 1 (c) shows the lateral view of the pipeembedded system.

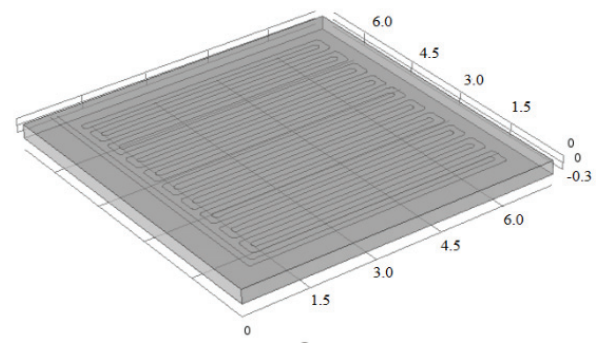

(a)

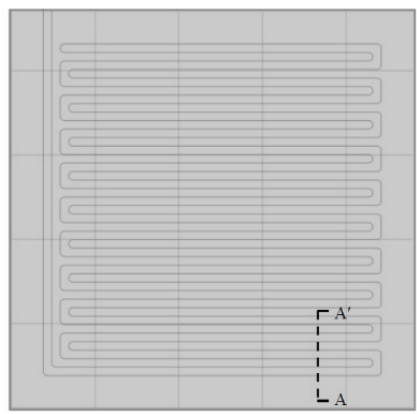

(b)

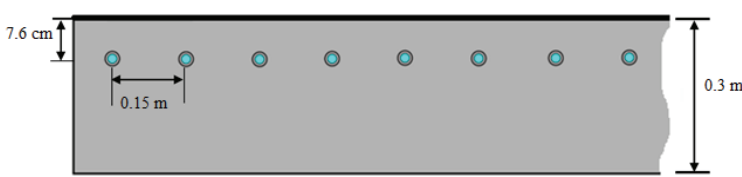

(c)

Figure 1. Hydronic snow-melting pavement with embedded pipes: (a) three-dimensional view of pipeembedded concrete panel, (b) top view of pipe layout, and (c) lateral view based on AA' cross-sectional areas.

\section{Heat Source and Techniques}

An alternative heat source for hydronically heated pavements is deep (as opposed to shallow) geothermal hot water, which comes from aquifers several hundred meters to several thousand meters deep. These deep aquifers are natural heat storage reservoirs that can supply water at high temperatures. This deep direct-use (DDU) geothermal hot water is an excellent heat source because of high-temperature geothermal hot water and its high economic value and the low-temperature geothermal hot water after power generation still can be used for space heating and snow-melting purposes. Based on these advantages, the cascading use of geothermal hot water has drawn much attention recently. In western North Dakota, previous investigations have shown that at least six aquifers in the Williston Basin can produce good quality high-temperature water. Although most previous studies have focused on geothermal hot water $\left(150^{\circ} \mathrm{C}\right.$ or above $)$ exploration, low-temperature geothermal hot water (below $150^{\circ} \mathrm{C}$ ) is available in these aquifers that are overlain by several major cities that have high heat demands. This low-temperature geothermal hot water is available within a relatively shallow depth compared to oil layers. Thus, DDU geothermal water can serve as an excellent heat source for snow-melting for transportation infrastructure.

Geothermal hot water has been used for pavement snow-melting in Japan since 1966 ([1], [13]). Hot spring water is circulated using three 10-hp pumps through three separate loops of pipe embedded three to five inches deep at one-foot spacings. The water flows in the three loops between $40 \mathrm{gpm}$ to $50 \mathrm{gpm}$ and the inlet temperatures are between $169^{\circ} \mathrm{F}$ and $181^{\circ} \mathrm{F}$. In the United States, the oldest geothermal pavement snow-melting system was installed in Klamath Falls, Oregon in 1948 by the Oregon Highway Department ([1]). Typically, the heat supplies at the original artesian flow of $20 \mathrm{gpm}$ are $3.5 \times 105 \mathrm{Btu} / \mathrm{hr}$ and $9.0 \times 105 \mathrm{Btu} / \mathrm{hr}$ at the pumped rate of $50 \mathrm{gpm}$. The latter energy supply rate can melt snow efficiently when the air temperature is $-23^{\circ} \mathrm{C}$ with a snowfall up to three inches per hour. According to a previous study ([3]. [4], [6]), water temperatures ranging from $30^{\circ} \mathrm{C}$ to $60^{\circ} \mathrm{C}$ are suitable for a hydronic system and can melt snow on pavements under most weather conditions in western North Dakota.

As shown in Figure 2, the scenario of two water supply wells, Davis and Homestead, were demonstrated. According to Gosnold et al. ([14]), the Davis well was drilled vertically to a depth of 2,163 meters and horizontally 1,494 meters in a high-porosity zone of the Lodgepole formation (Mississippian formation) for a total drilled length of 3658 meters (see Figure 2).

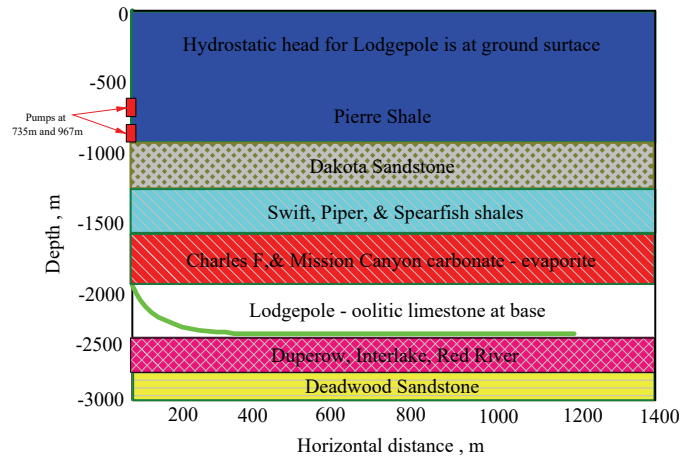

Figure 2. Cross-section of horizontal well drilling in Lodgepole formation (Modified Gosnold 2015 [14]).

The Homestead well, which also was drilled in the Lodgepole formation, was drilled vertically to a depth of 2,306 meters and horizontally 810 meters, for a total drilled length of 3,197 meters. These two water wells are able to supply a combined flow of $55.2 \mathrm{1} / \mathrm{s}$ at $98^{\circ} \mathrm{C}$. Also, the water at this site was found to have low amounts of total dissolved solids (TDS). Based on the drilling costs of these two wells, the two horizontal wells cost about $\$ 2$ million each according to Gosnold et al. ([14]). The produced water temperature was $103^{\circ} \mathrm{C}$ at the well head and $98^{\circ} \mathrm{C}$ at the inlets to the power plant; the well head and inlets were approximately 400 meters apart. The water was transported through uninsulated pipes buried below the frost line ([15]). Conceptually, through the 
available geothermal aquifers in western North Dakota and a feasible drilling technique, either co-produced water from oil and gas operations or newly-drilled wells can be applied to HHP systems as the heat sources.

\section{CLIMATIC CONDISITONS AND HIGH HEAT DEMANDS IN WINTER}

In North Dakota, the extreme continental climate of the north central United States leads to high demands for heating year round. The mean annual temperature in western and central North Dakota is $4.3^{\circ} \mathrm{C}$ and temperatures in the winter (December - April) average $13^{\circ} \mathrm{C}$. Climatic conditions are the most significant influential factor when a HHP system is designed. Moreover, North Dakota has higher heat demands in winter for melting snow than other areas in the United States, such as Alaska, New York City and Chicago; North Dakota has up to 25 percent higher heat demand than Alaska for snow melting ([3], [4], [6]). The climatic conditions need to be well considered including air temperature, snowfall rate, snowfall frequency, moisture content of the snow, wind speed, and amount of sunlight. Conventionally, the principles of the snow-melting process are based on raising the temperature of pavement surface to $32{ }^{\circ} \mathrm{F}\left(0{ }^{\circ} \mathrm{C}\right)$ or above to melt snow. Accordingly, the Chapman and Katunich eq. ([16]) has been widely used to estimate the heat requirements for melting snow considering climatic conditions. The Chapman and Katunich equation can be expressed mathematically as shown in Eq. (1).

$$
\mathrm{q}_{\mathrm{o}}=\mathrm{q}_{\mathrm{s}}+\mathrm{q}_{\mathrm{m}}+\mathrm{A}_{\mathrm{r}} *\left(\mathrm{q}_{\mathrm{h}}+\mathrm{q}_{\mathrm{e}}\right)
$$

where $\mathrm{q}_{\mathrm{o}}$ is the total heat flux per unit area of the surface, $\mathrm{Btu} / \mathrm{h} \cdot \mathrm{ft}^{2}\left(\mathrm{~W} / \mathrm{m}^{2}\right) ; \mathrm{q}_{\mathrm{s}}$ is the total sensible heat flux to bring snow to a melting point, $B t u / h \cdot \mathrm{ft}^{2}\left(\mathrm{~W} / \mathrm{m}^{2}\right) ; \mathrm{q}_{\mathrm{m}}$ is the melting load, $\mathrm{Btu} / \mathrm{h} \cdot \mathrm{ft}_{2}\left(\mathrm{~W} / \mathrm{m}^{2}\right) ; \mathrm{A}_{\mathrm{r}}$ is the ratio of the snowfree area to the total area (i.e., the snow-free area ratio); $\mathrm{q}_{\mathrm{h}}$ is the sum of the convection and radiation losses, $\mathrm{Btu} / \mathrm{h} \cdot \mathrm{ft}^{2}\left(\mathrm{~W} / \mathrm{m}^{2}\right)$; and $\mathrm{q}_{\mathrm{e}}$ is the evaporative loss, Btu/h$\cdot \mathrm{ft}^{2}$ $\left(\mathrm{W} / \mathrm{m}^{2}\right)$. Meanwhile, the efficiency of snow-melting will determine the amount of heat needed. the ratio of the snow-free area, $A_{f}$, to the total area, $A_{t}$, is defined as the snow-free area ratio, Ar. This ratio équation can be written as Eq. (2) ([4], [6], [16]):

$$
A_{r}=\frac{A_{f}}{A_{t}}
$$

where $A_{r}=1$ represents that the snow is totally melted on the pavement surface, whereas $A_{r}=0$ represents that the surface is completely covered with snow. In practical terms, the snow-free area ratio can reasonably be assumed to be a value between 0.5 and 1.0 .

According to Chapman and Katunich ([16]), for a snow-melting system design, the most important factor among these climatic conditions is the snowfall rate. When a snowfall event begins, the snowfall rate usually increases until the peak snowfall rate is reached. In this paper, the weather conditions considered for the heat requirement estimations are based on climatic data averaged over the 15 years from 2002 through 2016. These climatic data were measured by the National Oceanic and Atmospheric Administration and the World Data Center for Meteorology. Table 1 provides summaries of the averaged temperature, snowfall, and wind speed data for the four major cities (Bismarck, Minot, Williston, and Dickinson) that are targeted in this study. These climatic data must be considered when estimating the heat requirements for melting snow using the Chapman and Katunich equation ([16]). Overall, the optimized snow-melting system must be designed to melt snow under most circumstances.

Table 1. Averaged weather data obtained for four major cities in western North Dakota and used for heat estimations

\begin{tabular}{cccccc}
\hline & Jan. & Feb. & Mar. & Nov. & Dec. \\
\cline { 2 - 6 } $\begin{array}{c}\text { Air } \\
\text { Temperature, } \\
{ }^{\circ} \mathrm{C}\end{array}$ & -10 & -9.3 & -1 & -0.8 & -8.2 \\
$\begin{array}{c}\text { Snowfall, } \\
\mathrm{mm} / \mathrm{s}\end{array}$ & $9 \times 10^{-5}$ & $9 \times 10^{-5}$ & $8 \times 10^{-5}$ & $7 \times 10^{-5}$ & $1 \times 10^{-4}$ \\
$\begin{array}{c}\text { Wind Speed, } \\
\mathrm{m} / \mathrm{s}\end{array}$ & 4.5 & 4.2 & 4.5 & 4.2 & 4.5 \\
\hline
\end{tabular}

\section{FINITE ELEMENT ANALYSIS}

\subsection{Modeling of Hydronic Heating Pavement}

This paper focuses on assessing the effectiveness of hydronic pavement heating using geothermal hot water. This study considered the time-dependent heating process of piped pavements, the final temperatures of heated pavements, the final temperature drops of the hot water in the embedded pipes, and the required flow rates of the water circulating through the pipes. The feasibility of hydronic pavement heating using DDU geothermal hot water is addressed through the numerical modeling of the pavement heating process using the finite element technique. Numerical analyses were conducted to study the heat transfer mechanisms and time-dependent heating process for the proposed hydronic snow-melting system. COMSOL Multiphysics software using the finite element method was employed to carry out the computations. In COMSOL, two built-in laws of physics, non-isothermal pipe flow (nipfl) and heat transfer in solids (ht), were used to study the heat transfer that occurs in these two "Physics". The results of the finite element analysis were assessed based on the surface temperatures of the heated pavement panel and the outlet temperatures of the water that circulates through the pipes. Figures. 3 (a) and (b) show an example of the heat contours of the pavement and the temperature changes of the water circulating in the embedded pipes during the heating process, respectively. The lowest temperature of the circulating water is found at the outlet. After conducting a series of finite element analyses for hydronic pavement heating, the results indicate that the heat requirements for heating pavement can be satisfied using these temperatures of water (i.e., 30 ${ }^{\circ} \mathrm{C}$ to $60{ }^{\circ} \mathrm{C}$ ). Hot water at $60{ }^{\circ} \mathrm{C}$ is found to be able to melt snow under most weather conditions in west North 
Dakota, whereas water at $30{ }^{\circ} \mathrm{C}$ may have some limitations in melting snow under extremely low air temperatures. Nonetheless, the results show that the outlet temperatures of the water are still high and can be used in another panel if water temperatures at $50{ }^{\circ} \mathrm{C}$ or $60^{\circ} \mathrm{C}$ are used. For the circulating flow rate, $1 \mathrm{l} / \mathrm{s}$ is able to respond to most weather conditions, but $0.21 / \mathrm{s}$ may not work efficiently for low air temperatures $\left(-20^{\circ} \mathrm{C}\right.$ or lower) and will result in a higher temperature difference in the same pavement panel. The analysis results are presented in the following sections.

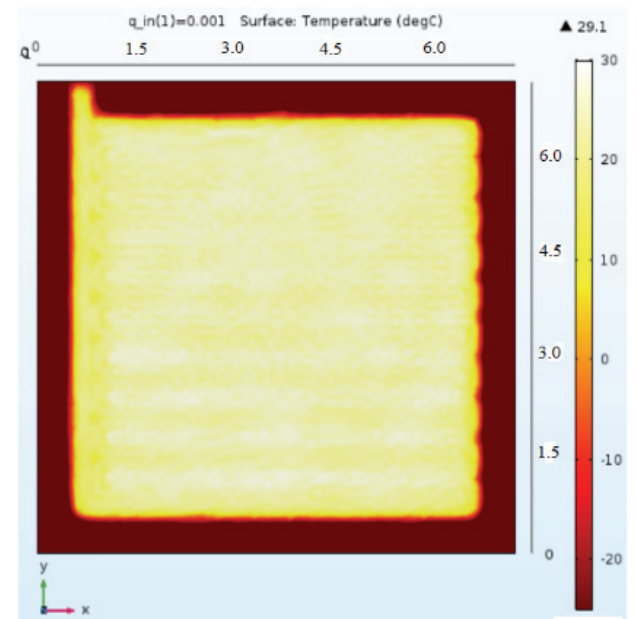

(a)

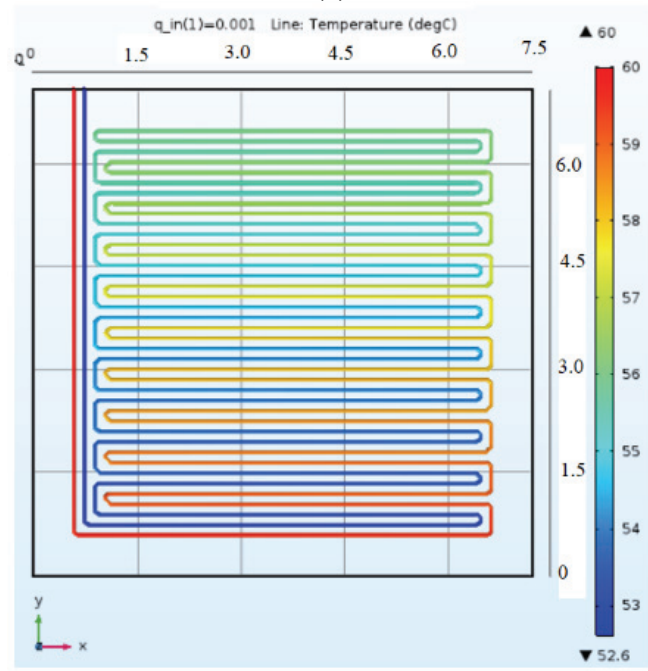

(b)

Figure 3. Contours of (a) surface temperature of heated pavement panel and (b) temperature of circulating water in the embedded pipes for heat flux $=300 \mathrm{~W} / \mathrm{m}^{2}$, inlet water temperature $=60^{\circ} \mathrm{C}$ at air temperature $=-25^{\circ} \mathrm{C}$, and volumetric flow rate $=11 / \mathrm{s}$.

\subsection{Properties, Boundary Conditions and Design of FEM Model}

\subsubsection{Panel Geometry, Material Properties and Boundary Conditions}

The numerical analysis focused on the heat transfer mechanisms, thus, the thermal properties and the mechanical properties of the materials needed to be defined. In the analysis, all the concrete panel was $7.3 \mathrm{~m}$ by $7.15 \mathrm{~m}$ by $0.3 \mathrm{~m}$ (see Fig. 1). The boundary conditions for the piped concrete that confine the heat flow are only at the top and bottom surfaces. The other four lateral surfaces were considered to be insulated, and thus, heat flow is not permitted. For the concrete, heavyweight concrete with a unit weight of $2300 \mathrm{~kg} / \mathrm{m}^{3}$ and thermal conductivity of $1.63 \mathrm{~W} / \mathrm{m} \mathrm{K}$ was assumed. For the pipe, typical PEX plastic pipes were modeled. For the water, the density and thermal conductivity were assumed to be $1000 \mathrm{~kg} / \mathrm{m}^{3}$ and $0.6 \mathrm{~W} / \mathrm{m} \mathrm{K}$, respectively. Table 2 lists the dimensions of the pipes and the volumetric flow rate of the water.

Table 2. Properties of pipe and volumetric flow rate of water

\begin{tabular}{ccccc}
$\mathrm{D}_{\mathrm{i}}(\mathrm{mm})$ & $\mathrm{D}_{\mathrm{o}}(\mathrm{mm})$ & $\mathrm{t}_{\mathrm{w}}(\mathrm{mm})$ & $(\mathrm{W} / \mathrm{m} \mathrm{K})$ & $\mathrm{q}_{0}\left(\mathrm{~m}^{3} / \mathrm{s}\right)$ \\
\hline 22.2 & 28.6 & 3.3 & 0.46 & 0.00155 \\
\hline $\begin{array}{l}\text { Note: } \mathrm{D}_{\mathrm{i}} \text { : inner diameter of pipe; } \mathrm{D}_{\mathrm{o}} \text { : outer diameter of pipe; } \\
\text { of pipe wall; } \mathrm{t} \text { : thickness conductivity of pipe material; }\end{array}$ & $\mathrm{q}_{0}$ : volumetric flow rate.
\end{tabular}

\subsubsection{Heat Requirements}

Considering all variables of weather conditions in western North Dakota including snowfall rate, ambient air temperature, humidity, and wind speed, Chapman and Katunich's eq. ([16]) provides the estimations of heat needed for snow-melting. In this analysis, the snow-free area ratio, $\mathrm{A}_{\mathrm{r}}=0.5$ and a $25 \%$ of heat loss at other boundaries were assumed. Table 3 provides a summary of of the estimated heat requirements for melting snow.

Table 3. Heat requirements for melting snow on pavement panels in western North Dakota $\left(\mathrm{A}_{\mathrm{r}}=0.5\right.$, and $\mathrm{Q}_{0}=1.25 \mathrm{q}_{0}$ )

\begin{tabular}{cccccc}
\multicolumn{6}{c}{$\left.\mathrm{Q}_{0}=1.25 \mathrm{q}_{0}\right)$} \\
& Jan. & Feb. & Mar. & Nov. & Dec. \\
\hline $\mathrm{q}_{0}, \mathrm{~W} / \mathrm{m}^{2}$ & 160.3 & 148.2 & 62.5 & 42.2 & 146.7 \\
$\mathrm{Q}_{0}, \mathrm{~W} / \mathrm{m}^{2}$ & 200.4 & 185.3 & 78.1 & 52.7 & 183.4 \\
\hline
\end{tabular}

\subsubsection{Parametric Study}

In the parametric analyses, several variables such as air temperature $\left(-25\right.$ to $\left.-5^{\circ} \mathrm{C}\right)$, required heat load $(250$ to 400 $\mathrm{W} / \mathrm{m}^{2}$ ), water temperature $\left(30\right.$ to $60^{\circ} \mathrm{C}$ ), volumetric flow rate of water $\left(0.0002\right.$ to $\left.0.001 \mathrm{~m}^{3} / \mathrm{s}\right)$, and thermal conductivity of concrete $\left(1.0\right.$ to $\left.2.0 \mathrm{~W} / \mathrm{m}^{\circ} \mathrm{K}\right)$ were studied.

Figure 4 shows the analysis results for water at $60^{\circ} \mathrm{C}$ and its heating process with respect to time under different air temperatures. In Figure 4, the temperature of the 
heated pavement rises to above $0^{\circ} \mathrm{C}$ after two hours of operation and starts to stabilize at constant temperatures after the system operates for about 10 hours.

Figure 5 shows the results for similar conditions but a lower volumetric flow rate for the hot water, i.e., $0.5 \mathrm{l} / \mathrm{s}$. The final temperatures of the heated pavements drop by

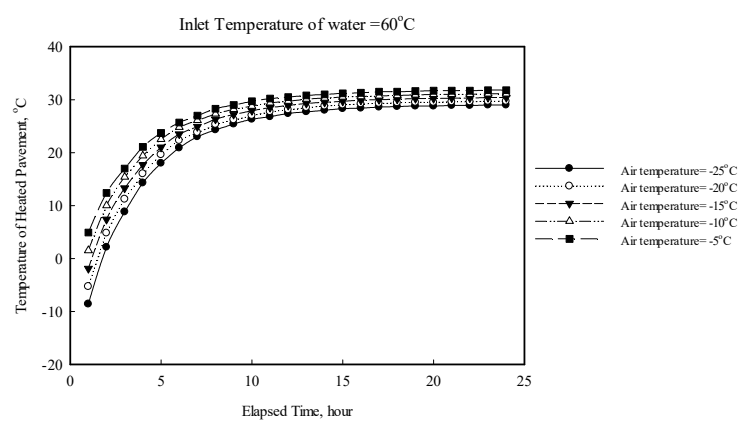

about $3^{\circ} \mathrm{C}$.

Figure 4. Temperatures of heated pavement versus time for heat supply $=300 \mathrm{~W} / \mathrm{m}^{2}$, inlet temperature of water $=$ $60^{\circ} \mathrm{C}$, and volumetric flow rate $=0.001 \mathrm{~m}^{3} / \mathrm{s}$.

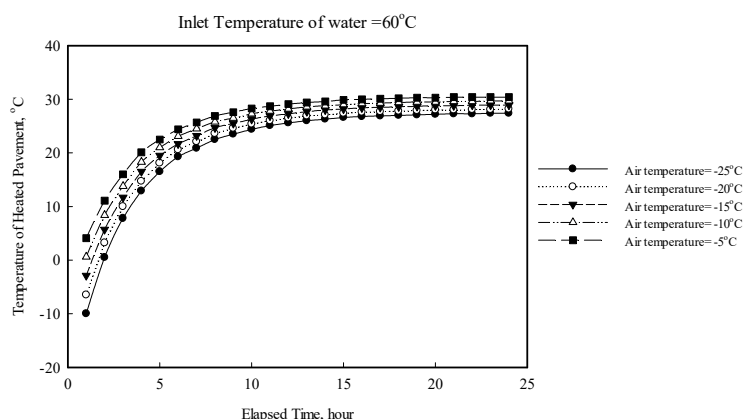

Figure 5. Temperatures of heated pavement versus time for heat supply $=300 \mathrm{~W} / \mathrm{m}^{2}$, inlet temperature of water $=$ $60^{\circ} \mathrm{C}$, and volumetric flow rate $=0.0005 \mathrm{~m}^{3} / \mathrm{s}$.

Figure 6 shows the relationship between the final temperatures of the heated pavements and the volumetric flow rate of the circulating water under different air temperatures. When using water temperature $=60^{\circ} \mathrm{C}$, the highest temperature of the heated pavements is about $23^{\circ} \mathrm{C}$ with the flow rate of $0.0002 \mathrm{~m}^{3} / \mathrm{s}$ under the air temperature of $-25^{\circ} \mathrm{C}$.

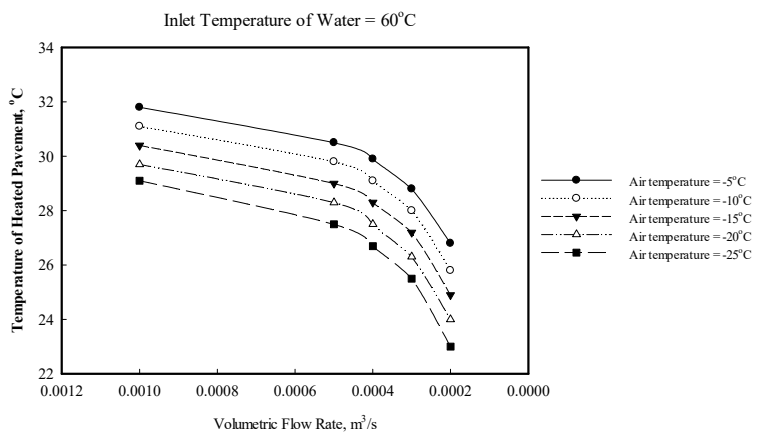

Figure 6. Final temperatures of heated pavement versus flow rate for heat supply $=300 \mathrm{~W} / \mathrm{m}^{2}$ and inlet temperature of water $=60^{\circ} \mathrm{C}$.
Figure 7 shows the relationship between the final temperatures of the heated pavements and the volumetric flow rate of the circulating water under different heat requirements for melting snow. For air temperature of $25^{\circ} \mathrm{C}$, the results show that the maximum temperature on the pavement can be heated up to $16^{\circ} \mathrm{C}$ when using the flow rate of $0.0002 \mathrm{~m}^{3} / \mathrm{s}$.

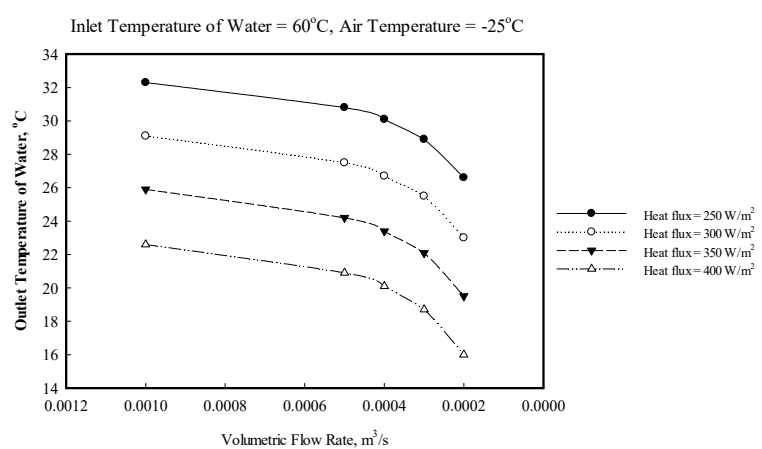

Figure 7. Resulting temperatures of heated pavement versus flow rate for inlet temperature of water $=60^{\circ} \mathrm{C}$ and air temperature $=-25^{\circ} \mathrm{C}$ under different heat requirements.

Figure 8 presents the relationship between the final temperatures of the heated pavements and the volumetric flow rate of the circulating water subjected to the air temperature of $-25^{\circ} \mathrm{C}$ and heat flux of $300 \mathrm{~W} / \mathrm{m}^{2}$ when using various inlet temperatures of water $(30,40,50$, and $60^{\circ} \mathrm{C}$ ). The results show that the maximum temperatures of the heated pavement are between $3.2^{\circ} \mathrm{C}$ and $-1.4^{\circ} \mathrm{C}$, depending on the flow rate of water with the inlet temperature of $30^{\circ} \mathrm{C}$.

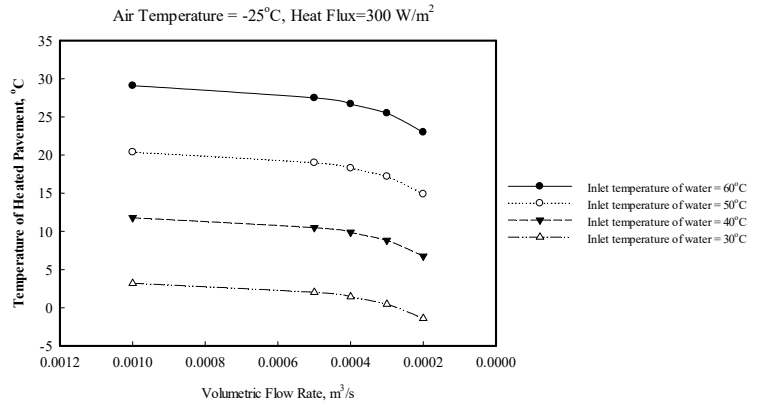

Figure 8. Temperatures of heated pavement versus flow rate for air temperature $=-25^{\circ} \mathrm{C}$ and heat flux $=300 \mathrm{~W} / \mathrm{m}^{2}$ when using various inlet temperatures of water.

The thermal conductivity of concrete pavement is significantly affects the effectiveness of snow-melting. The studied range of thermal conductivity of concrete material is from 1.0 to $2.0 \mathrm{~W} / \mathrm{m}^{\circ} \mathrm{K}$ while other conditions were kept constant: inlet temperature of water $=60^{\circ} \mathrm{C}$, volumetric flow rate $=0.5 \mathrm{~L} / \mathrm{s}$ and heat requirement $=300$ $\mathrm{W} / \mathrm{m}^{2}$. The analysis results are presented in Figure 9. 


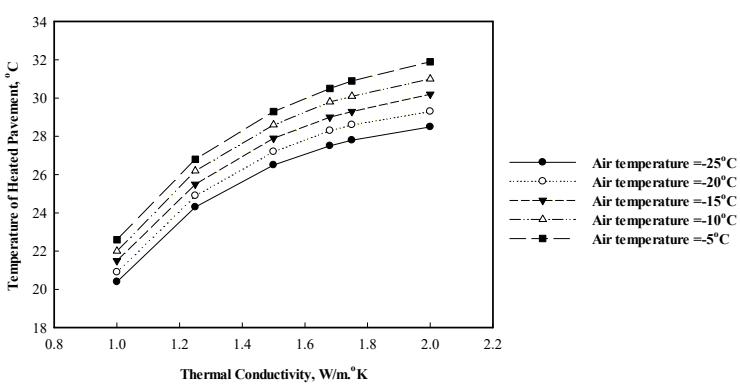

Figure 9. Final temperatures of heated pavement versus thermal conductivity of pavement material for inlet temperature of water $=60^{\circ} \mathrm{C}$ and volumetric flow rate $=$ $0.0005 \mathrm{l} / \mathrm{s}$.

\section{CONCLUSIONS}

The geological formations and petroleum industry provide the excellent conditions in western North Dakota to directly utilize geothermal hot water. Currently, the University of North Dakota is establishing a physical model of HHP to verify and optimize the design based on the results of parametric studies. The efficiency of the HHP depends on a few influential factors besides available temperature of water. Several conclusions can be drawn accordingly:

(1) The direct use of high temperature of water for the HHP can be used for melting snow in high heat demand area such as western North Dakota. Due to the availability and quantity, the priority of the applicable infrastructure is bridge deck.

(2) The heat requirement $=300 \mathrm{~W} / \mathrm{m}^{2}$ can satisfy most weather conditions in studied areas because the most severe snowfall events usually will not be accompanied by an extremely low temperatures and high wind speeds.

(3) Based on the currently scenario of pumping hot water, the low volumetric flow rate, $0.2 \mathrm{l} / \mathrm{s}$ and inlet water temperature $=60{ }^{\circ} \mathrm{C}$ used for the HHP is most efficiently.

(4) High thermal conductivity is favorable to pavement heating and optimizes using circulating hot water in the embedded pipes. Thus, higher conductivity of concrete should be considered in a HHP design.

The author would like to express appreciation for the NDDOT TRIP program that supported this research and would like to thank Dr. William Gosnold for his efforts with regard to related research preparations.

\section{References}

1. J.W. Lund, Geo-Heat Center Quarterly Bull. 21 (2), 12-19. (2000).

2. P. Anand, H. Ceylan, K. Gkritza, P. Talor, V.D. Pyrialakou, Civil, Construction and Environmental Engineering Conference Presentations and Proceedings. 9 (2014).
3. I.H. Ho, M. Dickson, Proceedings of the 1st Int. Conf. on Energy Geotechnics, ICEGT 2016, Kiel, Germany, 29-31 August. vol. 2016. Taylor \& Francis, London, 113-117 (2016)

4. I.H. Ho, M. Dickson, 2017. J. Geomech. Energy Environ. 10, 42-51 (2017).

5. V.V. Hai, D.W. Park, Adv. Mater. Sci. Eng. 2017, 17 (2017)

6. I.H. Ho, S. Li, S. Abudureyimu, J. Cold Regions Science and Technology. 160, 194-208. (2019).

7. Y. Hassan, A.O. Abd El Halim, A.G. Razaqpur, W. Bekheet, M.H. Farha, J. Transp. Eng. 128(4), 385391 (2002)

8. J.W. Lund, Geo-Heat Center Quarterly Bulletin, January, 1(3): 7-9 (1976).

9. J. P. Zarling, "High capacity intersection thaw system." School of Engineering, University of Alaska Fairbanks, Fairbanks, AK, (1995)

10. K. Melcher, Winter road maintenance spreadings in the Czech Republic and in EU countries, (2001)

11. K. Zwarycz, Poland Transportation Report, (2002).

12. R. Mirzanamadi, C.E. Hagentoft, P. Johansson, J. Johnsson, J. Cold Regions Science and Technology, Vol. 145: 106-118 (2018)

13. M. Sato, M. Sekioka, Geo-Heat Center Quarterly Bulletin 4, 16-18 (1979)

14. W. Gosnold, A. Crowell, S. Nordeng, M. Mann, GRC Transactions, 39, 653-660 (2015)

15. W. Gosnold, M. Mann, H. Salefar, AAPG Pacific Section and Rocky Mountain Section Joint Meeting, Las Vegas, Nevada, USA (2016)

16. W.P. Chapman, S. Katunich, Heat requirements of snow melting systems. ASHAE Transactions 62, 359-372 (1956) 